\title{
Trends in the Efficacy and Safety of Ingredients in Acne Skin Treatments
}

\author{
Ju Yeon Lee, Hyo Jeong Son* \\ Department of Cosmetics Engineering, Konkuk University, Seoul, Korea
}

"Corresponding author: Hyo Jeong Son, Department of Cosmetics Engineering, Konkuk University, 120 Neungdong-ro, Gwangin-gu, Seoul 05029, Korea

Tel.: +82 313425023

Email: oplpop@naver.com

Received December 27, 2017

Revised April 23, 2018

Accepted May 3, 2018

Published September 30, 2018

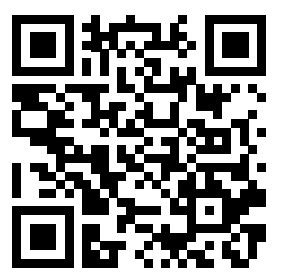

\begin{abstract}
The aim of this study is to explore trends in safety and efficacy of ingredients used in treatments for acne at a time when the distrust of chemicals is growing. 'Acne' is a chronic inflammatory follicular disorder of the skin. Propionibacterium acnes ( $P$. acnes) plays critical roles in the outbreak of acne by inducing inflammation and forming comedones. Currently, the main methods of treatment for acne vulgaris include oral antibiotics, anti-inflammatory drugs, retinoids, and topical medication. However, prolonged use of these drugs can cause side effects such as skin irritation, dryness, flushing, itching, and resistance to the drug. Thus, there is a demand for effective natural alternatives. Natural extracts that reduce bacterial activity to treat acne are expected to have significantly fewer side effects than existing medications. According to studies anti-bacterial effects are such as Nelumbo nucifera G., Corni fructus, Persicaria perfoliata, Taraxacum mongolicum H., Phragmitis rhizoma, Agrimonia pilosa, Lavandula offcinalis, Cymbopogon martini, Menthapiperita, Eucalyptus globulus, Camellia japonica, ceramide, propolis, epidermal growth factor (EGF) and so on. Further tests of the safety and efficacy of natural extracts with antibacterial properties compared to existing acne medications are needed.
\end{abstract}

Keywords: Propionibacterium acnes, Natural plant extracts, Anti-bacterial, EGF, Skin barrier

\section{Introduction}

인류는 예로부터 천연물을 질병 치료를 위한 의약품 원료로 요 긴하게 사용해 오고 있으며, 최근에는 화장품, 건강 기능성 식품 의 개발을 위해 다양하게 이용하고 있다(Kim et al., 2011a), 주 로 식물에 함유되어 있는 천연 생리활성 물질은 알칼로이드계 합 성경로, 테르펜계 합성경로, 플라보노이드계 합성경로, 폐놀계 합성경로의 네 가지 경로에 의해서 만들어진다. 이 물질들은 오 랫동안 주위의 생물들과 공전해오면서 종에 따라 복잡하고 다양 한 구조를 갖는 화합물로 진화하였다. 그리하여 식물체는 항산 화 물질과 더불어 미생물을 억제하는 항균 물질이 포함되었다 (Chan \& Kim, 2011; Han et al., 2006). 최근 각종 생활용품 에 유해 화학물질이 발견되면서 화학물질에 대한 염려를 넘어 공 포감을 느끼는 '케모포비아' 현상이 나타나고 있으며, 소비자들 사이에서 불안감이 확산되고 있는 상황이다. 이런 현실을 반영하 여 화장품 역시 성분을 중요시하는 소비자들이 천연물에 대한 관
심은 더더욱 높아질 것으로 예상된다. 여드름은 환경 및 스트레 스의 영향으로 청소년뿐만 아니라 성인에게도 흔히 발생하고 그 때문에 고통 받는 인구가 상당하다. 여드름은 심상성 좌창이라 불리는 만큼 피부의 염증반응 및 면역반응이 여드름 균 혹은 피 부장벽의 약화에 의해 장기적으로 일어나면서 불편을 겪게 되는 질환이다. 특히나 여드름 화장품에 사용되는 성분은 의약품과는 다르게 피부에 반복적으로 장기간 사용할 수 있어야 하기 때문에 안전성의 확보가 무엇보다 중요하다. 현재의 여드름 치료요법 및 보조요법으로 사용되는 약물들은 주로 건조함과 피부자극, 내성 의 부작용을 동반하므로 그 반응을 줄이면서도 여드름에 약리학 적 활성을 갖는 천연물과 피부장벽의 강화를 유도하는 성분에 대 한 자료가 필요하다. 이에 본 연구는 여드름 피부개선을 위한 안 전성을 확보하면서도 효능을 가지는 성분에 대해 기초자료를 제 시하고 여드름 화장품의 개발 자료로서 제공하고자 한다. 


\section{1. 여드름의 원인과 치료제 부작용 완화의 필요성}

여드름은 15 세에서 40 세 사이에 발생하는 피부질환으로, 특히 사춘기에 매우 흔한 질환으로 알려져 있으며, 모피지선에서 발생 한다. 면포, 구진, 농포, 낭종, 결절 등의 병변을 특징으로 하는 만성 염증성 질환으로 정의된다. 여드름을 일으키는 원인은 아직 확실하게 밝혀져 있지 않지만 크게 4 가지 즉 모공의 과각화, 피 지 분비 증가, 여드름 균의 증식, 모낭 부위의 염증 발생 등이 여 드름 발생의 주요 원인으로 지목되고 있다(Shin et al., 2008). 이런 다양한 원인에 의해 피부 모공이 막히게 되면 피부 상재균 인 P. acnes가 증식하면서 분비한 lipase가 피지내의 중성지방 을 분해하고 유리지방산을 형성한다. 그 후 백혈구를 모낭 주위 에 모이게 하여 모낭 벽을 자극하고, 파괴시켜 모낭 내용물이 진 피 내로 유입되면서 염증을 일으킨다(Brown \& Shalita, 1998; Koreck et al., 2003; Park et al., 2008a).

최근에는 4 가지 원인 외에 피부장벽 이상에 의하여 여드름이 발생하는 기전을 추가적인 병인으로 제시한다(Choi, 2006). 피 부 장벽이 손상되면 표피 내 칼슘이온의 농도가 변화하고 표피의 지질합성이 증가하게 된다. 또한 층판소체의 분비도 증가하고 각 질세포 사이의 지질 이중막이 형성되어, 기저층의 $\mathrm{DNA}$ 합성이 증가하게 되며 결국엔 피부장벽 손상이 회복된다(Lee \& Chung, 1999). 이때 세포에서 사이토카인(cytokine)을 분비하여 각질
형성세포의 증식을 자극하고, 다시 튼튼한 각질 세포간 지질막을 재형성하게 된다. 그러나 장벽손상이 지속되어 이들 사이토카인 이 만성적으로 분비하게 되면 오히려 염증과 표피증식 갈은 해로 운 결과를 가져오기도 한다(Choi, 2006; Jin \& Lee, 2014).

여드름의 약물치료는 피지 과잉생산 억제, 모낭벽의 과각 화 방지, P. acnes 균의 증식억제 및 염증반응의 방지측면에 서 개발되고 있으며, 현재는 여드름이 있는 부위에 직접 발라주 는 국소요법제와 경구복용제를 통한 전신요법이 사용되고 있다 (Sohn et al., 2006). 여드름 치료제는 증상의 정도에 따라 경증 일 경우 국소도포제(topical treatment)를 주로 사용한다. 그 예 로 benzoyl peroxide, salicylic acid, sulfur, azelaic acid 및 retinol 등을 들 수 있고(Bojar et al., 1995; Russell, 2000), 항생제 연고는 erythromycin, clindamycin 등이 주로 사용된다 (Ross et al., 1997). 중증의 경우 국소 도포제와 경구 복용제가 동시에 이용되며 benzoyl peroxide, clindamycin phosphate, erythromycin, tetracycline, isotretinoin 등이 주로 사용되고 있다(Lee \& Choi, 2006). 위 약물들은 여드름 형성 억제를 위해 정도의 차이는 있지만 강력한 면포 용해 기능을 가지고 있고 여 드름 균의 증식을 억제하며 염증반응을 완화 시키는 효능이 있어 치료효과를 증진시킨다(Kim et al., 2009). 그러나 이 약물들은 장기간 사용 했을 때 피부자극과 건조함, 홍조, 가려움의 부작용

Table 1. Demographic characteristics of the sample

\begin{tabular}{|c|c|c|c|}
\hline Medicine & Application method & Effect & Side effect \\
\hline $\begin{array}{l}\text { Salicylic acid } \\
\text { Sulfur } \\
\text { Resorcinol }\end{array}$ & External application & $\begin{array}{l}\text { Keratolysis } \\
\text { Pore expansion } \\
\text { Weak anti-bacterial }\end{array}$ & $\begin{array}{l}\text { Dry skin } \\
\text { Irritation }\end{array}$ \\
\hline Alpha-hydroxy acid & External application & $\begin{array}{l}\text { Remove dead skin cells. } \\
\text { Prevents pore blockage due to keratinocytes }\end{array}$ & $\begin{array}{l}\text { Dry skin } \\
\text { Irritation }\end{array}$ \\
\hline Benzoyl peroxide & External application & Reduces acne-causing bacteria. & $\begin{array}{l}\text { Dry skin } \\
\text { Irritation }\end{array}$ \\
\hline $\begin{array}{l}\text { Antibiotics } \\
\text {-Erythromycin } \\
\text {-Clindamycin } \\
\text {-Tetracycline }\end{array}$ & $\begin{array}{l}\text { External application } \\
\text { Oral administration }\end{array}$ & $\begin{array}{l}\text { Anti-bacterial } \\
\text { Anti-inflammatory }\end{array}$ & Antibiotic resistance \\
\hline Retinoids & External application & $\begin{array}{l}\text { Regulates follicular cell regeneration. } \\
\text { Assists in keratolysis. } \\
\text { Inhibits formation of comedones. }\end{array}$ & $\begin{array}{l}\text { Keratogenesis } \\
\text { Increases ultraviolet ray sensitivity }\end{array}$ \\
\hline Adapalene & External application & $\begin{array}{l}\text { Similar to retinoids } \\
\text { Anti-inflammatory }\end{array}$ & $\begin{array}{l}\text { Red skin } \\
\text { Dry skin } \\
\text { Stinging } \\
\text { Itching }\end{array}$ \\
\hline Azelaic acid & External application & $\begin{array}{l}\text { Anti-bacterial } \\
\text { Anti-inflammatory } \\
\text { Promotes skin renewal. } \\
\text { Prevents pore blockage due to keratinocyte. }\end{array}$ & Burning, stinging or tingling of the skin \\
\hline Isotretinoin & Oral administration & $\begin{array}{l}\text { Reduces the production of sebum. } \\
\text { Shrinks sebaceous glands. } \\
\text { Prevents comedones from forming. } \\
\text { Stabilizes keratinization. } \\
\text { Reduces inflammation in inflammatory acne. }\end{array}$ & $\begin{array}{l}\text { Dry skin } \\
\text { Birth defects } \\
\text { Scaling, redness, burning, pain, or other signs } \\
\text { of inflammation of the lips }\end{array}$ \\
\hline
\end{tabular}


을 유발하거나 내성이 발생하여 치료효과가 떨어질 수 있다. 이 외에 레티노이드의 기형 유발 가능성 및 $P$. acne의 항생제에 대 한 내성을 가질 확률 증가의 보고는 기존 치료의 한계로 여겨진 다(Kim \& Lee, 2009; Suh et al., 2016). 여드름 치료제를 사 용함에 있어서 부작용으로 발생되는 자극 증상은 이미 여드름이 라는 피부질환 자체가 손상된 피부장벽을 가지고 있고 또한 여 드름 치료제의 기제로 사용된 성분이 피부장벽을 더욱 손상시키 는 역할을 함으로써 발생할 수 있다(Choi, 2006; Table 1).

\section{P. acnes에 항균작용을 가지는 천연 추출물}

\section{1) 동백나무}

동백나무(Camellia japonica)는 동백나무과(Theaceae), 동 백속(Camelliae)에 속하는 상록교목으로 주로 남해안 및 도서지 역과 서쪽으로는 대청도, 동쪽으로는 울릉도까지 분포한다(Lee et al., 2005). 동백나무의 씨는 예로부터 전통적으로 중국에서 건위제와 항염증제로 사용되어 왔으며 줄기의 메탄올 추출물은 지질 및 산화 억제 등의 효과가 있음이 보고 되었다(Yoshikawa et al., 1994). 피부질환을 유발하는 5종의 미생물에 대한 동백 나무 잎 추출물 항균효과 실험은 dimethyl sulfoxide (DMSO) 에 $0.5,1,5 \mathrm{mg} / \mathrm{mL}$ 로 희석하여 처리한 동백나무 잎 추출 물로 억제직경 및 최소성장저해농도(minimum inhibitory concentration, $\mathrm{MIC}$ )를 측정한 결과, 동백나무 잎 추출물의 P. acnes에 대한 항균효과는 $0.25,0.5,1 \mathrm{mg} / \mathrm{mL}$ 에서 각각 $10.3,13.6,17.2 \mathrm{~mm}$ 의 억제직경이 나타났으며, MIC는 19.72 $\mu \mathrm{g} / \mathrm{mL}$ 로 나타났다(Kim \& Han, 2014). P. acnes에 대한 동백 나무 잎을 이용한 다른 실험의 연구결과로는 동백나무 잎 찐차 의 항균능을 실험하였으며, paper disc method와 agar plate method의 방법으로 실험을 하였다. 친수성 성분과 친유성 성분 으로 분획하여 실험한 결과로는 동백나무 잎 EtOAc 층에서는 항균능을 보이지 않았고, 친수성 동백나무 잎 찐차 추출물에서 뛰어난 항균능을 보여주었다. $100 \mu \mathrm{g} / \mathrm{mL}$ 의 ampicillin의 clear zone 지름은 $2.5 \mathrm{~cm}$, 친수층의 경우 clear zone 지름은 1.9 $\mathrm{cm}$ 였고, 동백나무 잎 친수층은 항생제인 ampicillin 대비 0.56 의 값을 보였다. P. acnes의 항균 정량화 실험에서는 친수성 동 백나무 잎 찐차 추출물에 대해 $86.94 \%$ (standard deviation $(\mathrm{S} . \mathrm{D})=20$.$) 의 항균능을 보였으며, 농도 및 처리양을 늘릴수$ 록 항균능이 향상되는 농도 의존적 경향을 보였다(Choi et al., 2012). 그 외에 동백나무잎 에탄올 추출물에서 Malassezia furfur (M. furfur)에 대하여 항균효과가 있으며(Kim \& Han, 2014), 동백나무 잎-가지 추출물에서 nitric oxide (NO) 및 prostaglandin E2 (PGE2) 생성량을 유의적으로 억제하여 항염 효과(Kim et al., 2013), 항산화와 항암효과가 나타났다(Kim et al., 2010b).
2) 연

연(Nelumbo nucifera G.)은 수생식물 중 부엽식물에 속하는 쌍떡잎식물로써 아시아 남부, 북호주가 원산지이며 우리나라에 서도 주로 연못에서 자생하고 논밭에서 재배되기도 한다(Borsch \& Barthlott, 1983; Dahlgren \& Rasmussen, 1983). 연잎 에서 분리된 생리활성 성분으로는 nelumboside, nuciferine, coclaurine 등의 alkaloid류, galic acid와 methyl gallate 등 의 aromatic acid류 및 quercetin, isoquercitrin, hyperoside, rutin, kaempferol 등의 flavonoid 류가 있다(Cho et al., 2003a; Furukawa, 1966; Kashiwada et al., 2005). 연잎 $50 \%$ ethanol 추출물은 P. acnes, Staphylococcus aureus ( $S$. aureus), Staphylococcus epidermidis (S. epidermidis) 등 3 종의 균주에 대해 항균성이 가장 높게 나타났으며, paper disc diffusion 법을 이용하여 측정한 결과, P. acnes 균주에서는 $12.31 \mathrm{~mm}$ 으로 나타났다. $\mathrm{MIC}$ 를 측정한 결과, 3 가지 피부상재 균 중 $S$. aureus에 대한 $50 \%$ ethanol 추출물의 MIC는 $250 \mu \mathrm{g} /$ $\mathrm{mL}$ 으로 항균활성이 가장 높았으며, P. acnes 균주에 대한 MIC 는 $500 \mu \mathrm{g} / \mathrm{mL}$ 으로 나타났다.

연잎 추출물은 염증 억제 및 피부 재생과 관련된 항산화 작 용을 나타낼 뿐만 아니라, RAW 264.7 세포를 이용한 세포실 험에서는 NO와 cyclooxygenase 2 (COX2)를 억제하는 항염 증 활성을 보고하였다(Lee et al., 2012a). 그 외에 연잎 추 출물의 tyrosinase 저해 효과(Yoo et al., 2015), 항산화 효 과 및 TYPE I procollagen의 생합성 촉진효과, 특히 matrix metalloproteinase-1 (MMP-1) 생성 억제효과가 나타났다 (Yang et al., 2006).

3) 산수유

산수유(Corni fructus)는 층층나무과(Cornaceae)에 속하 는 산수유나무(Cornus officinalis)의 과육으로 가을에 익은 붉 은색 열매의 씨를 제거하고 햇빛에 말려 건조한 과육을 말한다 (Chung et al., 1993). 예로부터 한의학에서 중요한 약제로 사 용되어 왔으며, 다뇨증, 요통, 이명, 폐결핵 등의 치료제로 간경 화, 신경에 좋고, 혈압하강, 항암 및 항균작용 등이 한의학에서 보고되고 있다(Seo et al., 1999). 산수유의 화학성분은 gallic acid, malic acid, tartaric acid, ursolic acid, morroniside, loganin, sweroside 등과 같은 배당체, tellimagrandin 1,2 , 1,2,3-tri-O-galloyl- $\beta$-D-glucose, 1,2,6-tri-O-galloyl$\beta$-D-glucose, 1,2,3,6-tetra-O-galloyl- $\beta$-D-glucose, gemin $\mathrm{D}$, 탄닌 성분으로 cornusin $\mathrm{A}-\mathrm{G}, 2,3-\mathrm{di}-\mathrm{O}-$ galloylD-glucose, 1,7-di-Ogalloyl-D-sedoheptullose 등이 있다 (Tian et al., 2000; Toheu \& Chiro, 1973). 산수유 에탄올 추 출물의 P. acnes 균주에 대한 $\mathrm{MIC}$ 는 $15.6 \mu \mathrm{g} / \mathrm{mL}$ 으로 항균효 과를 나타냈으며, 염증성 사이토카인들의 mRNA 발현 감소 효 
과가 있었다. P. acnes로 유도된 염증성 유전자 COX2의 단백 질 발현은 산수유 추출물에 의해 감소효과가 나타나 염증억제 에 도움이 되는 결과를 보였다(Choi et al., 2015). 그 밖에 산수 유 추출물의 $S$. aureus, S. epidermidis 및 E. coli에 대한 항균 (Yang, 2016), B16/F10 melanoma 세포주의 멜라닌 색소 감소 (Yang et al., 2002), 항산화(Seo et al., 1999), 항암(Kwon et $a l ., 2009)$ 효과 등이 보고 되었다.

\section{4) 며느리배꼽}

며느리배꼽(Persicaria perfoliata)은 원산지가 아시아 지역 인 마디풀과의 한 종류이다. 며느리배꼽은 예로부터 민간 치 료제로 해독제, 해열제, 이뇨제 등으로 사용되어 왔으며, 기침 이나 백일해 등 호흡기 질환에도 사용되어 왔다(Jang et al., 2003; Jovanovic et al., 1996). 며느리배꼽 추출물의 주요 성 분으로는 ferulic acid, vanillic acid, quercetin, caffeic acid, protocatechuic acid 등이 있다(Adachi et al., 2002; Ahn et al., 2009; Yang \& Park, 2008). P. acnes에 대한 며느리배꼽 $50 \%$ ethanol 추출물의 MIC는 $0.5 \%$ 이고, ethyl acetate 분획 은 $0.25 \%$ 로 나타났으며, $S$. aureus에 대한 며느리배꼽 추출물 중 ethyl acetate 분획의 MIC는 $0.25 \%$ 로, methyl paraben의 MIC $0.25 \%$ 와 비교하여 동일한 항균활성을 나타내고 있다. 항산 화 활성과 항균활성 그리고 ethyl acetate 분획과 aglycon 분획 의 tyrosinase와 elastase의 저해 활성으로부터 며느리배꼽 추 출물의 항산화, 항노화 및 항균작용을 보고 하였다(Ahn et al., 2009).

\section{5) 민들레}

민들레(Taraxacum mongolicum H.)는 국화과(Compositae) 에 속하는 다년초로(Cho et al., 2003b) 특히 폴리페놀화합 물 중 플라보노이드, 루테올린, 시나믹산, 쿠마린, 타락사스테 롤 등의 성분 및 엽록소와 비타민 $\mathrm{C}$ 가 많이 함유되어 있다(Park et al., 2008b). 민들레는 진균바이러스를 억제하는 작용도 하 며 각기병 치료제, 목욕제품 등 화장품 원료로도 사용되며 비 타민 C외에도 아미노산 등의 영양물질이 함유되어 있기 때문 에 화장품 첨가제로 쓰이며, 유기산이 함유되어 있어 그 추출물 은 화장품의 방부제로도 쓰인다(Ju et al., 2004). 민들레의 항 균활성에 대한 연구로 4 종의 여드름 균 Plasmodium ovale (P. ovale), $P$. acnes, Pseudomonas aeruginosa (P. aerujionsa), $S$. aureus를 이용한 실험에서 민들레의 에탄올 용매 추출물에 서는 P. ovale 균에서만 우수한 항균효과가 있었고 다른 3 종 의 P. acnes, P. aerujionsa, S. aureus 균주에서는 증류수 용 매 추출물이 우수한 항균활성을 나타내었다. 민들레 에탄올 추 출물은 P. ovale균에서 $63.98 \mathrm{mg} / \mathrm{L}$, 민들레 증류수 추출물은 $S$. aureus균에서 $66.86 \mathrm{mg} / \mathrm{L}$ 로 가장 낮은 농도를 나타냈다
(Chan \& Kim, 2011). 그 외에 tyrosinase 저해 활성, B16/F1 melanoma 세포주의 멜라닌 색소 감소효과가 나타났으며(Kang \& Yoo, 2009), 활성화된 mast cell에서 발현하는 cytokine 인 interleukin 4 (IL4), interleukin 5 (IL5), interleukin 6 (IL6), interleukin 13 (IL13)의 생성을 억제함으로써 알레르 기 염증 반응을 효과적으로 조절되었다(Jang et al., 2012). 또 한 2,2-diphenylpicrylhydrazyl (DPPH) radical 소거능과 $\mathrm{OH}$ radical 소거능은 지상부 메탄올 추출물에서 가장 높게 나타났으 며, 결장암 및 위암에 대해 항암효과를 나타난 것으로 보고되었 다(Heo \& Wang, 2008).

6) 노근

노근(Phragmitis rhizoma)은 키가 큰 여러해살이 풀인 갈대 Phragmites communis Trin. (벼과, Gramineae)의 근경(根 본이다. 노근의 약리학적 효능은 해열작용, 진액 생성, 구토 억 제, 항암작용, 해독작용 등이 있으며 coixol의 성분이 다량 함유 되어 있어 항염 작용, 과산화물을 제거하는 항산화 작용, 배란유 발 작용, 항알러지 작용, 항히스타민 작용, 항경련제 작용을 보 고하고 있다(Kim et al., 1998; MO et al., 2013). 노근의 항균 효과에 대한 실험 결과로는 $P$, acnes 균주에 노근 열수 추출물 $20.0 \mathrm{mg} / \mathrm{disc}$ 로 처리 시, $8.2 \mathrm{~mm}$ 크기의 clear zone이 나타났 고, 에탄올 추출물로 처리했을 때 $20.0 \mathrm{mg} / \mathrm{disc}$ 에서 $9.8 \mathrm{~mm}$ 크기의 clear zone이 나타났다. 노근 에탄올 추출물이 열수 추출 물 보다 항균력이 더 우수하게 나타났으며, 특히 S. epidermidis 와 P. acnes 균주의 항균활성이 $S$, aureus 균주 보다 약간 더 좋은 것으로 확인 되었다. P. acnes 균주는 5 가지 분획물 실험 중 ethyl acetate 분획물에서 좋은 활성이 있는 것으로 보고 되 었다(Mo \& Oh, 2011). DPPH radical 소거능과 superoxide dismutase (SOD)유사 활성도는 에탄올 추출물이 높은 것으 로 나타나 항산화 효과도 높은 것으로 보고하였다(Mo et al., 2013).

\section{7) 선학초}

선학초(Agrimonia pilosa)는 장미과에 속하는 다년생 숙근 초로서 북반구 온대와 브라질 및 남아메리카 둥에 10 여종이 분 포하며, 우리나라에서는 들이나 길옆에 어느 지역에서나 잘 자 라는 식물로 짚신나물이라 부른다(Lee, 2006; Park \& Lee, 2000). 선학초의 성분들은 전초에 agrimonin, agrimonolide, tormentic acid, ellagic acid 등이 있고 잎과 줄기에는 luteolin-7-glucoside이 함유되어 있다(Pei et al., 1990). 선학 초 메탄올 추출물 $0.05 \%$ 의 농도에서 paper disk dilution 법을 이용하여 측정한 결과, P. acnes, S. aureus, S. epidermidis, Bacillus subtilis (B. subtilis), Bacillus cereus (B. cereus) 5 종의 균주 중 $P$. acnes 균주에 $36 \mathrm{~mm}$ 로 항균성이 가장 높게 나 
타났으며, MIC는 $50 \mu \mathrm{g} / \mathrm{mL}$ 으로 나타났다(Kim et al., 2006). 그 외 tyrosinase 활성 억제(Kim et al., 2011b), tyrosinase 단 백질 및 mRNA 발현 억제(Kim et al., 2010a), NO, inducible nitric oxide synthase (iNOS) 및 COX2 억제, tumor necrosis factor alpha (TNF $\alpha)$, interleukin 1 beta (IL1 $\beta)$, IL6 염증반 응 억제 효과(Hwang et al., 2016), 항산화, 항암 효과가 보고 되었다(Min et al., 2008).

\section{Essential oil}

Essential oil은 아로마테라피에 주로 사용되는 천연식물성 정 유로서 여러가지 추출 방법을 통해 얻어진 방향성 오일 성분이다 (Lee et al., 2012b). Essential oil은 다양하게 응용하여 사용할 수 있는데 다양한 질병의 치료를 위한 보조요법 또는 마사지, 화 장품의 원료와 방향제 등으로 널리 사용된다.

\section{1) 라벤더}

라벤더(Lavandula offcinalis) 오일은 지중해 지방에서 자생 하는 다생초본으로 주 산지는 프랑스, 스페인, 영국이다. 라벤더 는 심신의 안정과 밸런스를 유지시켜 불면증, 우울증 치료에 효 과적이며, 마음을 차분하게 하고 소염, 항 박테리아 작용이 있 어 피부 질환에 폭 넓게 사용하고 일광 화상, 상처치유에 효과 적이며 피지 분비 조절작용이 있어 여드름 피부에도 효과적으 로 사용 가능하다(Yoo \& Na, 2010). 라벤더 오일의 성분으로 는 에스테르 성분인 linalyl acetate (48.00\%)와 모노테르펜 알 코올 성분인 linalool (18.60\%)이 가장 많은 구성 비율을 차지 하며, caryophyllene (3.10\%), farnesene (2.01\%)과 같은 세 스퀴테르페노이드 성분도 함유하고 있다. 또한 1.8-cineole (1.59\%)과 같은 옥사이드 성분도 미량 함유하고 있음을 최근 연 구에서 확인하였다. 라벤더 $10 \%$ 농도에서 P. acnes 균에 대해 4 $\mathrm{mm}$ 이상의 clear zone이 측정되어 항균효과가 나타났으며, $P$. ovale, C. albicans 균에서도 매우 우수한 항균활성이 나타났고, $1 \%$ 농도에서는 $S$. aureus 균에 대해 $1.5 \mathrm{~mm}$ 의 항균력이 나타 났다(Shin et al., 2012a). 그 외에 라벤더 에탄올 추출물에서 $\alpha$-melanocyte-stimulating hormone $(\alpha-\mathrm{MSH})$ 에 의하여 촉 진된 멜라닌의 생성과 수지상 돌기 형성 억제 효과, $\alpha-\mathrm{MSH}$ 에 의하여 증가된 tyrosinase 활성도와 tyrosinase mRNA 발현 감 소효과(Kim et al., 2008) 및 항산화 효과가 있다(Chae et al., 2011).

\section{2) 팔마로사}

팔마로사(Palmarosa)의 학명은 Cymbopogon martini이 고, 과명(family)은 Poaceae 계열이며 인도 전통 의학에서는 열 을 내리거나 소화기 계통 질환에 쓰여왔다. 팔마로사는 방부, 해 열, 소화 촉진, 살균, 세포 자극과 세포 성장력으로 주름이나 여
드름 피부에 효과적이며 소화기계통에 대한 강장제로 장내 세균 중에 유해균에 대항하는 역할을 하여 위의 근육을 강화시키거나 식욕을 자극하고 수분 밸런스를 회복시켜 주어 건성 피부에 사 용하였다(Oh, 2000). 팔마로사의 주요 성분으로는 geraniolo이 $72.55 \%$ 로 가장 많은 비중을 차지하며, b-citronellol 및 geranyl acetate가 주성분이고 이는 테르펜알콜류에 속한다. P. acnes에 대한 팔마로사의 항균효과를 확인해 본 결과, 팔마로사는 $1 \%$ 및 $10 \%$ 농도에서 모두 높은 항균력을 나타내었다. 팔마로사의 주요 성분인 geraniol도 $1 \%$ 와 $10 \%$ 농도에서 높은 항균력을 보였고, 팔마로사의 주요 성분인 geraniol은 팔마로사의 항균력에 영향 을 미치는 것으로 예측되고 있다. 그 외에 Candida albicans $(C$. albicans)은 $1 \%$ 와 $10 \%$ 농도, S. aureus은 $10 \%$ 의 농도에서 항 균력이 나타났으며, Escherichia coli (E. coli)에서도 항균력이 나타난 것으로 보고되었다(Lee et al., 2012b).

\section{3) 페퍼민트}

페퍼민트(peppermint, Mentha piperita)는 유럽에서 주로 자 생하며 이 식물에서 추출한 essential oil은 연간 3,500 톤 정도 의 큰 소비시장을 형성하고 있는 대표적인 허브오일이다(Hyun et al., 2015). 페퍼민트 오일은 페퍼민트 잎을 수증기로 증류하 여 추출한 것으로서, 주성분은menthol이 25-62\%로 가장 많은 비율을 차지한다. 그 외 휘발성 오일(0.32-4\%), menthon (1340\%), methofman (1-4\%) 및 limonene (0-25\%)으로 구성되 어 있다(Ji et al., 2011). 그 중 menthol은 피부와 근육을 시원 하게 해주고 국지적인 진통효과가 강해 통증을 완화시키는 마사 지 오일이나 크림에 사용된다(Wilson, 2002). 페퍼민트는 항균 및 항 바이러스 작용, 항 종양 작용이 알려져 있다(Krystyna \& Magdalena, 2014). 여드름 균을 대상으로 한 항균 실험에서도 P. acnes KCTC 3320 균주에 대해 $52.8 \mathrm{~mm}$ 로 가장 강한 단독 활성의 항균효과를 나타내었다(Min, 2015). 그 외에 항산화 및 항암효과가 보고되었다(Krystyna \& Magdalena, 2014).

\section{4) 유칼립투스}

유칼립투스(Eucalyptus globulus)는 도양과에 속하며 호주 에 자생하고 있는 나무로 가까운 주변국가 뉴기니와 인도네시 아 멀리는 필리핀에 극히 소수만이 자라고 있으며 몇 종류들 은 미국, 영국, 아프리카, 지중해, 중앙아시아, 중국 및 인도 대 륙에서 재배되고 있다. 유칼립투스의 주성분은 1,8-cineole과 $\alpha$-terpineol 인데 1,8-cineole을 함유한 essential oil들의 효 과로는 항균, 항산화 및 항염 효과가 보고되어 있다(Tsai et al., 2011). 유칼립투스는 예로부터 여러가지 감염증과 열병 치료에 사용되어 왔다. 또한 유칼립투스 오일은 감염, 화상, 상처, 염증 이 있거나 칙칙하고 정체된 피부에 효과가 있고, 머리를 맑게 해 주며 감정을 진정시키는 효과가 있다고 알려져 있다(Lee et al., 
2016). P. acnes에 대한 항균 실험으로는 유칼립투스 오일을 $10,25,50 \%$ 의 농도로 실험을 진행하였는데 $50 \%$ 의 농도에서 clear zone 크기가 각각 $54.98 \mathrm{~mm}, 34.97 \mathrm{~mm}$ 로 나타나 높은 항균력을 보임을 알 수 있었다. 또한 이 실험에서는 유칼립투스 오일을 단일로 사용했을 때보다 레몬오일과 혼합해서 사용했을 때 P. acnes에 대한 항균활성이 증대되었다(Kim et al., 2011c). 이처럼 다양한 식물 추출물과 essential oil은 여드름 균에 항 균활성을 나타낸다는 것을 확인할 수 있었다. 이 내용을 아래 Table 2에 정리하였다.

\section{4. 피부장벽의 정상화를 통한 여드름 피부의 개선}

1) 세라마이드

여드름 개선을 위한 치료 보조요법으로 피부장벽의 강화 및 개 선을 주장하는 논문들이 있다. 피부장벽을 손상시키는 몇 가지 종류의 자극을 반복적으로 무모생쥐의 피부에 주었을 때 피부장 벽 손상과 함께 공통적으로 표피 증식이 일어나는 것을 확인하였 다. 이는 피부장벽이 손상되면서 각질형성세포가 사이토카인을 분비하고, 각질형성세포의 증식을 직접 자극함으로써 진피내 염 증세포에서 분비된 사이토카인에 의하여 각질형성세포의 DNA 합성이 증가되어 표피 증식을 초래한다. 이렇게 손상된 피부장벽
을 보이는 아토피 피부염 등의 치료 보조제로 사용되고 있는 가 성 세라마이드가 포함되어 multilamellar emulsion (MLE)형태 를 가지는 피부장벽 대체 치료(barrier replacement therapy)를 시행하였을 때, 면포의 육안적 크기를 줄이고 현미경적 구조도 줄이는 결과를 보였다(Choi, 2006).

\section{2) 프로폴리스}

프로폴리스(propolis)는 꿀벌이 유해한 세균이나 바이러스로부 터 벌집을 보호하고 청결한 환경을 유지하기 위하여 수목에서 수 집한 수액에 밀랍이나 수액을 혼합시켜 만든 점착성이 있는 수액 상의 천연물질로, cinnamic acid, cinnamic alcohol, chrysin, methyl protocatechuic aldehyde, isovanillin, acacetin, pinostrobin-5-oxa-4,7-dimethoxyflavanone, 5,7-dioxo3,4-dimethoxyflavone, 5-oxa-4,7 dimethoxyflavone 등 의 다양한 플라보노이드(flavonoids)와 폴리페놀(polyphenol) 이 세포막 강화, 세포 작용을 활성화하고, 콜라겐의 합성을 도 우며, 결합조직이나 혈관, 피부 등을 튼튼히 하는데 효과가 있 어 오래 전부터 유럽 지역에서 민간요법으로 알러지 비염과 천 식 및 여러 피부질환의 치료나 미용적인 목적으로 사용되어 왔다 (Lee et al., 2009). 프로폴리스 추출물 $0.05 \%$ 농도로 처리했을

\section{Table 2. Effectiveness of natural plant extracts}

\begin{tabular}{|c|c|}
\hline Scientific name & Effects \\
\hline Lavandula offcinalis & $\begin{array}{l}\text { S. aureus, } P \text {. acnes, } P \text {. ovale, } C \text {. albican antibiosis effect, DPPH radical elimination, tyrosinase } \\
\text { inhibition activity, reduced tyrosinase mRNA expression, inhibition of dendrite formation by } \alpha \text {-MSH }\end{array}$ \\
\hline Cymbopogon martini & P. acnes, C. albicans, S. aureus, E. coli anti-biosis effects \\
\hline Mentha piperita & P. acnes anti-biosis, anti-oxidant, anti-cancer effect \\
\hline Eucalyptus globulus & Anti-inflammatory, anti-oxidant, anti-infective, antibacterial \\
\hline Camellia japonica & $\begin{array}{l}\text { P. acnes, } M \text {. furfur anti-biosis effect, NO \& PGE2 inhibition activity, DPPH radical elimination, } \\
\text { anticancer }\end{array}$ \\
\hline Nelumbo nucifera G. & $\begin{array}{l}\text { P. acnes, } S \text {. aureus, } S \text {. epidermidis antibiosis effect, inhibition of ROS formation, NO \& COX2 } \\
\text { inhibition, DPPH radical elimination, xanthine oxidase inhibition, tyrosinase inhibition activity, reduced } \\
\text { protein expression and mRNA inhibition expression of MITF, TRP1, TRP2, tyrosinase }\end{array}$ \\
\hline Corni fructus & $\begin{array}{l}\text { S. aureus, } S \text {. epidermidis, E. coli antibiosis effect, manifestation of IL1 } \alpha \text {, TLR2, activity of NF-KB, } \\
\text { DPPH radical elimination, melanin pigment reduction effect of B16/F10 melanoma cell line, anti- } \\
\text { cancer effect. }\end{array}$ \\
\hline Persicaria perfoliata & $\begin{array}{l}\text { S. aureus anti-biosis effect, free radical elimination, ROS inhibition, inhibition of tyrosinase and } \\
\text { elastase }\end{array}$ \\
\hline Taraxacum mongolicum $\mathrm{H}$. & $\begin{array}{l}\text { P. ovale, S. aureus, } P \text {. aerujinosa anti-biosis effect, DPPH radical elimination, } \mathrm{OH} \text { radical elimination, } \\
\text { tyrosinase inhibition activity, B16/F1 melanoma cytosis decreased melanin, inhibition of generation } \\
\text { of cytokine IL4, IL5, IL6, and IL13, anti-cancer effect }\end{array}$ \\
\hline Phragmitis rhizoma & S. epidermidis, $P$. acnes anti-biosis effect, DPPH radical elimination, SOD activity \\
\hline Agrimonia pilosa & $\begin{array}{l}\text { P. acnes antibiosis effect, DPPH radical elimination, tyrosinase active inhibition, inhibition of } \\
\text { tyrosinase protein and mRNA expression, NO and iNOS, COX2 inhibition, inhibition of inflammation in } \\
\text { TNF } \alpha \text {, IL1 } \beta \text {, IL6, anti-cancer effect }\end{array}$ \\
\hline
\end{tabular}


때 P. acnes 항균활성이 현재 여드름 국소 치료제로 사용되는 $1 \%$ clindamycin과 3\% benzoyl peroxide와 비슷한 항균활성을 나타 낸 것으로 in vitro 실험 결과를 통해 보고한 것을 참고하여, 프 로폴리스 함유 하이드로겔 조성물을 3 주간 아침, 저녁 2 회씩 0.5 $\mathrm{mL}$ 를 도포한 in vivo 실험 결과, 성인 여드름의 염증 완화, 붉은 자국 및 색소 침착 완화에 효과가 있는 것으로 보고 하였다. 또 한 경피수분손실량은 사용 1 주후에는 감소량이 적었으나 2 주, 3 주 후 지속적으로 감소하여 각각 $2.9,3.5,4.0$ 및 $4.3 \mathrm{~g} / \mathrm{h} / \mathrm{m}^{2}$ 으로 급격히 감소하여 유의한 차이가 있는 것으로 확인하였고 이 실험결과는 프로폴리스 함유 하이드로겔 조성물의 사용으로 여드 름 피부의 장벽 기능이 개선되었음을 확인한 것으로 보고하였다 (Park et al., 2012).

\section{3) 표피성장인자}

표피성장인자(epidermal growth factor, $\mathrm{EGF}$ )는 쥐의 침샘 에서 발견된 첫 성장인자이며, 각질세포의 표면과 모낭, 땀샘, 피 지샘의 세포에 발현된 표피성장인자 수용체(epidermal growth factor receptor, EGFR)에 신호전달 역할을 한다(Cohen, 1962; Nanney, 1990). 표피성장인자 억제 항암제를 사용할 경우 75$100 \%$ 에서 여드름 양상의 모낭염이 발생된다고 보고되고 있다. 표피성장인자는 지방형성을 억제하여 세포 내 중성 지방 농도를 낮춘다고 알려져 있으며, 재조합 인간 표피성장인자를 도포할 경 우, 여드름 발진이 임상적으로 호전되고, 여드름에 도포할 경우 피지 분비량이 감소하고, 피부 수분량이 증가한다고 알려져 있다 (Cohen, 1962; Sato et al., 2001; Shin et al., 2012b). EGF 함유 외용제를 하루에 두 번 여드름이 발생한 부위에 EGF 함유 컨트롤과 모이스처를 도포하도록 한 실험에서 피지량은 사용 전 $528.24 \pm 583.68$ 개에서 사용 2 주 후 $446.24 \pm 518.07$ 개, 사용 4 주 후 $393.76 \pm 445.55$ 개로 감소하였다. 경표피수분손실량은 사용 전 $19.41 \pm 5.35 \mathrm{~g} / \mathrm{h} \cdot \mathrm{m}^{2}$ 에서 사용 2주 후 $17.59 \pm 5.34 \mathrm{~g} /$ $\mathrm{h} \cdot \mathrm{m}^{2}$, 사용 4 주 후 $17.76 \pm 5.07 \mathrm{~g} / \mathrm{h} \cdot \mathrm{m}^{2}$ 로 감소하였다. 통계적 으로도 사용 전과 비교하여 사용 2 주 후부터 유의하게 경표피수 분손실량이 감소하였고 피부 홍조, 개방/폐쇄 면포, 구진의 유의 한 감소를 확인하였다(Suh et al., 2016).

\section{Conclusion}

본 논문은 최근 케모포비아 현상과 같은 화학제품의 전반적인 불안감에서 시작된 소비자들의 천연물 관심증가를 바탕으로 작성 되었다. 여드름 피부에 개선을 위해 부작용이 적은 안전한 천연 물질 혹은 대체물질을 이용한 연구 동향을 파악하고 여드름 항균 효과를 가진 천연물들의 효능에 대한 기초자료를 제공하고자 한 다.
동백나무 추출물로 피부질환을 유발하는 5 종의 미생물에 대 한 동백나무 잎 추출물 항균효과 실험은 억제직경 및 $\mathrm{MIC}$ 를 측 정한 결과, 동백나무 잎 추출물의 $P$. acnes에 대한 항균효과가 있었다. 연잎 50\% ethanol 추출물에서 paper disc diffusion 법 을 이용하여 MIC를 측정한 결과, $50 \%$ ethanol 추출물에서 항균 활성이 가장 높은 것으로 나타났다. 산수유는 에탄올 추출물에서 P. acnes에 대한 항균효과가 나타났으며, P. acnes에 의해 유발 된 NHEKs 세포주의 염증모델에서 IL1 $\alpha$, TLR2의 발현, NFkB 의 활성, $\mathrm{COX} 2$ 의 단백 발현이 염증매개물질에 대한 염증 억제 효과가 나타나 여드름 치료 및 예방에 실용성이 있음을 보고 하 였다. 며느리배꼽은 P. acnes와 $S$. aureus에 대한 항균 실험에 서 ethyl acetate 분획이 항균효과가 나타나 며느리배꼽추출물이 항균제로 응용될 수 있는 가능성을 시사하였다. 민들레의 항균 활성에 대한 연구 즉 4종의 여드름 균인 P. ovale, P. acnes, $P$. aerujionsa, $S$, aureus를 이용한 실험에서 민들레의 에탄올 용매 추출물에서는 $P$. ovale 균에서만 우수한 항균효과가 있었고, $P$. acnes, $P$. aerujionsa, $S$. aureus에 대한 항균효과는 증류수 추 출물에서만 나타났다. 노근은 에탄올 추출물이 열수 추출물 보다 항균력이 더 우수하게 나타났으며, S. epidermidis와 P. acnes 균주의 항균활성이 $S$. aureus 균주 보다 약간 더 좋은 것으로 나 타났다. 선학초는 메탄올 추출물 $0.05 \%$ 의 농도에서 paper disk diffusion법을 이용하여 측정한 결과, $P$. acnes, $S$. aureus, $S$. epidermidis, B. subtilis, B. cereus 5 종의 균주 중 $P$. acnes 균 주에 대한 항균성이 가장 높게 나타났다.

라벤더오일은 심신의 안정과 밸런스를 유지시켜 불면증, 우울 증 치료에 효과적이며, 마음을 차분하게 하고 소염작용, 항 박테 리아 작용이 있어 피부 질환에 폭 넓게 사용하고 일광 화상, 상 처치유에 효과적이며 피지 분비 조절작용이 있어 여드름 피부에 도 효과적으로 사용이 가능하다. 팔마로사는 실험을 진행한 모 든 농도에서 높은 항균력을 나타내었다. 팔마로사의 주요 성분 인 geraniolo이 팔마로사의 항균력에 영향을 미치는 것으로 생각 된다. 페퍼민트는 항균 및 항 바이러스 작용, 항 종양 작용이 알 려져 있고 여드름 균을 대상으로 한 실험에서도 P. acnes KCTC 3320 균주에 대해 강한 항균효과를 나타내었다. 유칼립투스의 $P$. acnes에 대한 항균 실험에서 $50 \%$ 농도의 유칼립투스 오일이 높 은 항균력을 보임을 나타내었다. 또한 유칼립투스 오일을 단일로 사용했을 때보다 레몬오일과 혼합해서 사용했을 때 $P$. acnes에 대해서 항균활성이 증대되는 것으로 보고되었다.

위의 천연 추출물과는 다른 방법으로 여드름 피부의 개선과 부 작용 및 자극이 적은 것으로 보고되는 성분은 피부장벽의 개선을 목적으로 하며, 아토피피부염 등의 치료 보조제로 사용되는 가 성 세라마이드가 포함되어 multilamellar emulsion 형태를 가 지는 피부장벽 대체 치료(barrier replacement therapy)제가 있 다. 이 성분을 도포하여 여드름 피부에 적용하였을 때에 면포의 
육안적 크기 및 현미경적 구조도 줄이는 결과를 보였다. 프로폴 리스 추출물 효능은 $0.05 \%$ 농도를 처리했을 때 항균활성이 현재 여드름 국소 치료제로 사용되는 $1 \%$ clindamycin과 $3 \%$ benzoyl peroxide와 비슷한 항균활성을 나타낸 것으로 보고하였다. 표피 성장인자는 지방형성을 억제하여 세포 내 중성 지방 농도를 낮춘 다고 알려져 있다. 재조합 인간 표피성장인자를 여드름 피부에 도포할 경우, 여드름양 발진이 임상적으로 호전되고, 피지분비량 의 감소와, 피부 수분량이 증가한다고 알려져 있다. 위의 내용을 종합해 볼 때 여드름의 항균활성이 있는 천연추출물이나 천연성 분 그리고 피부의 장벽을 개선시켜 수분균형을 유지하게 해주는 성분들을 여드름 피부에 적용했을 때 치료제 만큼의 효과가 있을 것으로 생각된다.

다양한 천연추출물과 essential oil 들이 여드름 균에 항균효 과를 나타내고 있고 여드름 치료제로 사용되는 성분들의 부작용 에 대응하기 위해 피부장벽과 피부의 면역을 개선 할 수 있는 다 른 대체 성분들의 연구가 활발하게 이루어지고 있지만 현재 여드 름에 사용되고 있는 치료제와 천연추출물 및 대체성분의 비교연 구는 부족한 실정이다. 앞으로 여드름 화장품이 기능성화 되는 추세에 따라 안전성과 안정성이 확보된 기존 치료제와 천연추출 물의 비교 연구가 필요하며, 보다 효과적으로 항 여드름 균 효과 가 있고 부작용이 없는 추출물 및 대체 성분에 대한 연구가 지속 적으로 이루어져야 할 것이다.

\section{References}

Adachi Y, Akamatsu H, Horio T. The effect of antibiotics on the production of superatigen from Staphylococcus aureus isolated from atopic dermatitis. Journal of Dermatological Science, 28: 76-83, 2002.

Ahn YJ, Kim SY, Ok JH, Wang H, Park CH, Kim SH, Heo YS, Jeon YH, Park SN. Antioxidant activity of Persicaria perfoliata extracts. Journal of the Society of Cosmetic Scientists of Korea, 35: 235-241, 2009.

Bojar RA, Cunliffe WJ, Holland KT. The short-term treatment of acne vulgaris with benzoyl peroxide: effects on the surface and follicular cutaneous microflora. British Journal of Dermatology, 132: 204-208, 1995.

Borsch T, Barthlott W. Classification and distribution of the genus Nelumbo adans (Nelumbonaccae). Beitrage zur Biologie der Pflanzen, 68: 421-450, 1983.

Brown SK, Shalita AR. Acne vulgaris. Lancet, 351: 18711876, 1998.

Chae IG, Yu MH, Kim HI, Lee IS. Anti-inflammatory and anti- oxidative activity of methanol extract from Terminalia chebula Retz., Lavandula spica L., and Dalbergia odorifera T. in RAW 264.7 cells. Journal of Life Science, 21: 561-567, 2011.

Chan GY, Kim HJ. Antimicrobial effects of extracts of Taraxacum officinale $\mathrm{H}$. on acnes strains. Intentional Journal of Complementary, Integrative and Alternative Medicine, 7: 3-16, 2011.

Cho EJ, Yokozawa T, Rhyu DY, Kim SC, Shibahara N, Park JC. Study on the inhibitory effects of Korean medicinal plants and their main compounds on the 1,1-diphenyl2-picrylhydrazyl radical. Phytomedicine, 10: 544-551, $2003 a$.

Cho SY, Oh YJ, Park JY, Lee MK, Kim MJ. Effect of dandelion (Taraxacum officinale) leaf extracts on hepatic antioxidative system in rats fed high cholesterol diet. Journal of the Korean Society of Food Science and Nutrition, 32: 458-463, 2003b.

Choi EH. Pimples and skin barrier. The Journal of Skin Barrier Research, 8: 42-46, 2006.

Choi JY, Song SY, Lee HH. Antibacterial and antiinflammatory activity of Corni Fructus ethanol extract in Propionibacterium acnes. Asian Journal of Beauty and Cosmetology, 13: 623-630, 2015.

Choi MH, Ryu EM, Oh DS, Shin HJ. Improvement of acne condition in skin care using Camellia japonica L. extracts. Asian Journal of Beauty and Cosmetology, 10: 661-672, 2012.

Chung SR, Jeune KH, Park SY, Jang SJ. Toxicity and lectins constituents from the seed of Cornus officinalis. Korean Journal of Pharmacognosy, 24: 177-182, 1993.

Cohen $\mathrm{S}$. Isolation of a mouse submaxillary gland protein accelerating incisor eruption and eyelid opening in the new-born animal. Journal of Biological Chemistry, 237: 1555-1562, 1962.

Dahlgren R, Rasmussen FN. Monocotyledon evolution: characters and phylogenetic estimation. Evolutionary Biology, 16: 255-395, 1983.

Furukawa H. On the alkaloids of Nelumbo nucifera Gaertn. XII. alkaloids of loti embryo. Yakugaku Zasshi, 86: 75$77,1966$.

Han SH, Woo NRY, Lee SD, Kang MH. Antioxidaitve and antibacterial activities of endemic plants extracts in Korea. Korean Journal of Medicinal Crop Science, 14: 
49-55, 2006.

Heo SI, Wang MH. Antioxidant activity and cytotoxicity effect of extracts from Taraxacum mongolicum $\mathrm{H}$. Korean Journal of Pharmacognosy, 39: 255-259, 2008.

Hwang JH, Nam JH, Kim WK, Bae HS. Effects of agrimoniae herba 30\% ethanol extract on LPS-induced inflammatory responses in RAW264.7 macrophage cells. The Korea Journal of Herbology, 31: 63-69, 2016.

Hyun HB, Boo KH, Kang HR, Cho SK. Analysis of mint essential oils from Jeju island, Korea by gas chromatographymass spectrometry and headspace-gas chromatographymass spectrometry. Applied Biological Chemistry, 58: 175-181, 2015.

Jang MH, Choi JS, Bae NY, Ahn TW. Effects of TAM (Taraxacum mongolicum) on Th2 cytokine production in MC/9 mast cells. Journal of Sasang Constitutional Medicine, 24: 5465, 2012.

Jang SY, Ryu SY, Kim SD. Antifungal activity of plant extracts against Pityrosporum ovale and Candida albicans. Korean Journal of Pharmacognosy, 34: 303-307, 2003.

Ji JR, Choi YM, Song DY, Choe HS, Na CS, Shim KS. Effect of feeding peppermint (Mentha piperita L.) powder on meat quality and fatty acid composition in finishing Korean native black pigs. Korean Journal for Food Science of Animal Resources, 31: 224-231, 2011.

Jin SP, Lee DH. Epidermal structure and skin barrier. The Journal of Skin Barrier Research, 16: 5-12, 2014.

Jovanovic SV, Steenken S, Hara Y, Simic MG. Reduction potentials of flavonoid and model phenoxyl radicals. which ring in flavonoids is responsible for antioxidant activity? Journal of the Chemical Society, Perkin Transactions 2, 11: 2497-2504, 1996.

Ju YS, Kim KY, Jang SH. Beauty donguibogam. SungBoSa, Seoul, p149, 2004.

Kang JR, Yoo SM. A study on effect on skin whitening action in Taraxacum platycarpum fractions. Asian Journal of Beauty and Cosmetology, 7: 199-206, 2009.

Kashiwada Y, Aoshima A, Ikeshiro Y, Chen YP, Furukawa H, Itoigawa M, Fujioka T, Mihashi K, Cosentino LM, MorrisNatschke SL, Lee KH. Anti-HIV benzylisoquinoline alkaloids and flavonoids from the leaves of Nelumbo nucifera, and structure-activity correlations with related alkaloids. Bioorganic \& Medicinal Chemistry, 13: 443448, 2005.
Kim BJ, Lee SJ. Aesthetic dermathlogy. Yeomungak publishing, Seoul, pp124-127, 2009.

Kim CM, Shin MG, An DG, Lee KS. The encyclopedia of oriental herbal medicine. Jungdam publishing, Seoul, pp955-958, 1998.

Kim DH, An BJ, Lee JY. Whitening activities of the Agrimonia pilosa L. extracts. Applied Biological Chemistry, 54: 284289, 2011b.

Kim DS, Kim YM, Woo WH, Mun YJ. Study of inhibitory effect of melanogenesis and antioxidant activity of Agrimonia pilosa Ledeb. Journal of Physiology \& Pathology in Korean Medicine, 24: 236-241, 2010a.

Kim HJ, Lee DJ, Ku JJ, Choi K, Park KW, Kang SH, Moon C, Lee PJ. Anti-inflammatory effect of extracts from folk plants in Ulleung island. Korean Journal of Plant Resources, 26: 169-177, 2013.

Kim HJ, Lim HW, Kim BH, Kim HS, Choi SW, Yoon CS. Studies on the anti-acne effect of Agrimonia pilosa Ledeb. Journal of the Society of Cosmetic Scientists of Korea, 32: 53-58, 2006.

Kim HM, Jang YM, Han KS, Moon DW, Mun YJ, Woo WH. Effect of the ethanol extract from Lavandula vera on $\alpha-\mathrm{MSH}$ induced melanogenesis. Journal of Physiology \& Pathology in Korean Medicine, 22: 1444-1448, 2008.

Kim HS, Lee HY, Lee JN, Joo CG, Choi TB. The effects of antimicrobial properties of manuka oil and improvement of acne. Journal of the Korean Society of Cosmetology, 17: 245-256, 2011 a.

Kim JH, Jeong $\mathrm{CH}$, Shim $\mathrm{KH}$. Antioxidative and anticancer activities of various solvent fractions from the leaf of Camellia japonica L. Korean Journal of Food Preservation, 17: 267-274, 2010b.

Kim JH, Kim MJ, Choi SK, Bae SH, An SK, Yoon YM. Antioxidant and antimicrobial effects of lemon and eucalyptus essential oils against skin floras. Journal of the Society of Cosmetic Scientists of Korea, 37: 303308, 2011c.

Kim N, Lim YH, Park SW, Nam ES. Antimicrobial activities of the anti-acne compounds from natural sources. Microbiology and Biotechnology Letters, 37: 80-84, 2009.

Kim YR, Han JS. Antimicrobial effects of Camellia japonica leaf extract on skin disease-related microorganisms and its antioxidative activity. Journal of Investigative 
Cosmetology, 10: 13-19, 2014.

Koreck A, Pivarcsi A, Dobozy A, Kemény L. The role of innate immunity in the pathogenesis of acne. Dermatology, 206: 96-105, 2003.

Krystyna SW, Magdalena W. Preparative separation of menthol and pulegone from peppermint oil (Mentha piperita L.) by high-performance counter-current chromatography. Phytochemistry Letters, 10: xciv-xcviii, 2014.

Kwon SH, Yang HS, Kim JY, Park KW, Shon MY, Kang KS, Shim KH, Seo KI. Biological activities of ethanol extract from Corni fructus. Journal of the Korean Society of Food Science and Nutrition, 38: 287-291, 2009.

Lee CM, Park HJ, Lee SY, Oh KS. The effects of propolis administration and maximal exercise on acute inflammatory responses and immune functions in adult women. The Korean Journal of Growth and Development, 17: 41-49, 2009.

Lee EJ, Lee SH, Lim MH. Antimicrobial and antioxidative activities of essential oil-focused on Palmarosa (Cymbopogen martini) and Geranium (Pelargonium graveolens). Journal of the Korean Society of Cosmetology, 18: 136-143, $2012 \mathrm{~b}$.

Lee KS Choi JS. Biochemical properities, isolation \& identification of Propionibacterium acnes picked from acne lesion. Fashion \& Textile Research Journal, 8: 571576, 2006.

Lee SH, Chung TS. Understanding the skin barrier. The Journal of Skin Barrier Research, 1: 8-21, 1999.

Lee SJ, Lee EH, Shin JH, Kim SS, Kim NK, Choi E, Seo SR. Eucalyptus globulus extracts inhibit Propionibacterium acnes-induced inflammation signaling. Korean Journal of Microbiology, 52: 421-427, 2016.

Lee SS, Imm JY, Han YS. The improvement effect of Lotus leaf extracts on acne skin. Asian Journal of Beauty and Cosmetology, 10: 405-413, 2012a.

Lee SY, Hwang EJ, Kim GH, Choi YB, Lim CY, Kim SM. Antifungal and antioxidant activities of extracts from leaves and flowers of Camellia japonica L. The Korean Journal of Medicinal Crop Science, 13: 93-100, 2005.

Lee YN. Flora of Korea. Kyohaksa, Seoul, p302, 2006.

Min KJ, Song JW, Cha CG. The antioxidative and antitumor activity of extracts of Agrimonia pilosa. Journal of Food Hygiene and Safety, 23: 149-156, 2008.
Min YH. Antibacterial activity of essential oil blends against Propionibacterium acnes. Journal of Investigative Cosmetology, 11: 215-223, 2015.

Mo JH, Oh SJ. A study on P. Rhizoma extract's anti-micobial activity and cytotoxicity. Asian Journal of Beauty and Cosmetology, 9: 167-178, 2011.

Mo JH, Oh SJ, Kim KR. Comparison on the antioxidative activity of ethanol and hot water extracts of Phragmitis rhizoma. Journal of the Korean Society of Cosmetology, 19: 809-814, 2013.

Nanney LB. Epidermal and dermal effect of epidermal growth factor during wound repair. Journal of Investigative Dermatology, 94: 624-629, 1990.

Oh HG, Aromatherapy. Yangmoon, Seoul, pp82-95, 2000.

Park CH, Lee JY, Lee GW, Cho YH. The alleviating effect of moisturizer with propolis extracts on the adult acne inflammation and redness. Journal of Investigative Cosmetology, 8: 17-23, 2012.

Park JH, Lee CK. The encyclopedia medicinal plants. Shinil books, Seoul, p559, 2000.

Park JY, Park CM, Kim JJ, Song YS. Hepatoprotective activity of Dandelion (Taraxacum officinale) water extract against D-Galactosamine-induced hepatitis in Rats. Journal of the Korean Society of Food Science and Nutrition, 37: 177-183, 2008b.

Park SS, Sung SH, Ryu YB, Cho YU, Choi YJ, Park KH, Gal SW. Growth inhibition of Propionibacterium acnes by mycelial culture broth of Paecilomyces japonica in the mulberry leaf extract. Journal of Mushrooms, 6: 32-37, 2008a.

Pei YH, Li X, Zhu TR. Studies on the structure of a new ellagic acid glycoside from the root-sprouts of Agrimonia pilosa Ledeb. Acta Pharmaceutica Sinica, 25: 798-800, 1990.

Ross JI, Eady EA, Cove JH, Jones CE, Ratyal AH, Miller YW, Vyakrnam S, Cunliffe WJ. Clinical resistance to erythromycin and clindamycin in cutaneous Propionibacteria isolated from acne patients is associated with mutations in 235 rRNA. Antimicrobial Agents and Chemotherapy, 41: 1162-1165, 1997.

Russell JJ. Topical therapy for acne. American Family Physician, 61: 357-360, 2000.

Sato T, Imai N, Akimoto N, Ito A, Sakiguchi T, Kitamura K. Epidermal growth factor and $1 \alpha, 25$-dihydroxyvitamin D3 suppress lipogenesis in hamster sebaceous gland 
cells in vitro. Journal of Investigative Dermatology, 117: 965-970, 2001.

Seo KI, Lee SW, Yang KH. Antimicrobial and antioxidative activities of Corni Fructus extracts. Korean Journal of Food Preservation, 6: 99-103, 1999.

Shin JU, Park JH, Cho BC, Lee JH. Treatment of epidermal growth factor receptor inhibitor-induced acneiform eruption with topical recombinant human epidermal growth factor. Dermatology, 225: 135-140, 2012b.

Shin KH, Lee HS, Kim GC. Sebum of creation and acne. The Journal of Skin Barrier Research, 10: 56-60, 2008.

Shin YH, Kim HJ, Lee JY, Cho YJ, An BJ. Major compound analysis and assessment of natural essential oil on anti-oxidative and anti-microbial effects. Journal of Life Science, 22: 1344-1351, 2012a.

Sohn HY, Kim YS, Kum EJ, Kwon YS, Son KH. Screening of anti-acne activity of natural products against Propionibacterium acnes. Microbiology and Biotechnology, 34: 265-272, 2006.

Suh JH, Hyun MY, Jang SE, Choi SY, Kim MN, Kim BJ. Efficacy and safety of topical application of epidermal growth factor (EGF) for Korean acne patient. Journal of the Society of Cosmetic Scientists of Korea, 42: 111-118, 2016.

Toheu E, Chiro TH. Constituents of Cornus officinalis. Yakugaku Zasshi, 93: 30-36, 1973.

Tsai ML, Lin CC, Lin WC, Yang CH. Antimicrobial, antioxidant, and anti-inflammatory activities of essential oils from five selected herbs. Bioscience, Biotechnology, and Biochemistry, 75: 1977-1983, 2011.

Tian G, Zhang T, Yang F, Ito Y. Separation of gallic acid from Cornus officinalis Sieb. et Zucc by high-speed countercurrent chromatography. Journal of Chromatography $A$, 886: 309-312, 2000.
Wilson R. Aromatherapy: essential oils for vibrant health and beauty. Avery, A member of Penguin Putnam Inc, New York, pp107-109, 2002.

Yang HJ, Park SN. Component analysis of Suaeda asparagoides extracts. Journal of the Society of Cosmetic Scientists of Korea, 34: 157-165, 2008.

Yang HO, Choi WY, Jeon BH, Baek SH, Chun HJ. Water extract from Cornis Fructus regulates melanogenesis in B16/ F10 melanoma. Journal of Physiology \& Pathology in Korean Medicine, 16: 818-822, 2002.

Yang JC. A study on the cosmetic preservative effects of Cornus officinalis seed extracts. Journal of Oil \& Applied Science, 33: 333-341, 2016.

Yang WM, Kim HM, Chang MS, Park W, Kim WN, Kim SW, Choi DG, Lee HC, Kim YK, Park SK. Effects of ethanol extract of Nelumbo nucifera leaves on anti-oxidation and type I procollagen expression in CCD-986sk cells. The Korean Journal of Oriental Medical Prescription, 14: 67-75, 2006.

Yoo DH, Joo DH, Lee SY Lee JY. Antioxidant effect of Nelumbo nucifera G. leaf extract and inhibition of MITF, TRP-1, TRP-2, and tyrosinase expression in a B16F10 melanoma cell line. Journal of Life Science, 25: 11151123, 2015.

Yoo YS, Na MS. Inhibitory effect on acne using anti-bacteria of lavender essential oil in adolescents. Asian Journal of Beauty and Cosmetology, 8: 1-12, 2010.

Yoshikawa M, Harada E, Murakami T, Matsuda H, Yamahara J, Murakami N. Camelliasaponins B1, B2, C1 and C2, new inhibitors of ethanol absorption in rats from seeds of Camellia japonica L. Chemical and Pharmaceutical Bulletin, 42: 742-744, 1994. 


\section{국문초록}

\section{여드름 피부에 효능 및 안전성을 가진 성분의 연구동향}

이주연, 손효정*

건국대학교 화장품공학과, 서울, 한국

본 연구의 목적은 여드름 피부에 효능 및 안전성을 가진 성분에 대한 연구 동향을 알아보는데 있다. '여드름'은 만성 염증성 모낭염 질환이다. 여드름 균은 여드름 발생에 있어 염증 과정뿐만 아니라 코메돈(comedones)의 형성에 있어서 중요한 역할을 한다. 지금까 지, 일반적인 여드름 치료의 주요한 방법으로는 구강 항생제, 항염증제, 레티노이드 등이 있었다. 하지만 이런 약물들의 장기간 사 용은 피부자극, 건조, 홍조, 가려움과 내성 발생 등의 부작용을 유발하여 이를 대체할 수 있는 천연물 혹은 대체 성분에 대한 연구가 꾸준히 이어지고 있다. 특히 이 중에서도 박테리아 활동을 억제하는 자연 추출물은 기존 여드름 치료 약물의 부작용을 줄이면서도 여드름 균에 대한 효과가 입증되었다. 여드름 균에 대한 항균활성을 가지면서도 안전한 성분들로는 라벤더(Lavandula offcinalis), 팔마로사(Cymbopogon martini), 유칼립투스(Eucalyptus globulus), 페퍼민트(Menthapiperita), 동백나무(Camellia japonica), 연(Nelumbo nucifera G.), 산수유(Corni fructus), 며느리배꼽(Persicaria perfoliate), 민들레(Taraxacum mongolicum H), 노근 (Phragmitis rhizome), 선학초(Agrimonia pilosa), ceramide, propolis, epidermal growth factor (EGF) 등이 있었다. 앞으로 더 많은 연구를 통해 여드름 균 저해 활성이 있는 천연 추출물과 대체성분을 활용 가능하도록 기존 치료제와 비교하여 연구해 볼 필요성이 있다.

핵심어: 여드름 균, 식물 추출물, 항균, 표피성장인자, 피부장벽

\section{참고문헌}

강정란, 유선미. 민들레분획물이 미백활성에 미치는 효과에 대한 연구. 아시안뷰티화장품학술지, 7: 199-206, 2009.

김나래, 임영희, 박설웅, 남은실. 천연물유래 여드름 치료제제의 항균활성 측정. 한국미생물·생명공학회지, 37: 80-84, 2009.

김대성, 김영목, 우원홍, 문연자. 선학초 추출물의 멜라닌합성 억제 및 항산화효과. 동의생리병리학회지, $24: 236-241$, 2010a.

김범준, 이상주. 에스테틱 피부과학. 여문각, 서울, $\mathrm{pp} 124-127,2009$.

김영례, 한진섭. 동백나무 잎 추출물의 피부질환균에 대한 항균효과와 항산화 활성. 대한미용학회지, 10: 13-19, 2014.

김지혜, 김민정, 최수기, 배승희, 안성관, 윤영민. 레몬 및 유칼립투스 에센셜오일의 피부 상재균에 대한 항산화 및 항균 효

과. 대한화장품학회지, 37: 303-308, 2011c.

김진희 정창호, 심기환. 동백나무 잎 용매분획물의 항산화 및 항암 활성. 한국식품저장유통학회지, 17: 267-274, 2010b. 김창민, 신민교, 안덕균, 이경순. 중약대사전. 정담 출판사, 서울, $\mathrm{pp} 955-958,1998$.

김현숙, 이혜영, 이재남, 주철규, 최태부. 마누카 오일의 항균효과와 여드름 개선 효과. 한국미용학회지, 17: 245-256, 2011.

김현주, 임혜원, 김보현, 김학수, 최신욱, 윤창순. 선학초 추출물의 항여드름 균 효능 연구. 대한화장품학회지, $32: 53-$ $58,2006$.

김현준, 이동준, 구자정, 최경, 박광우, 강신호, 문철, 이평재. 울릉도 민속식물 추출물의 항염증 효과. 한국자원식물학회 지, 26: 169-177, 2013.

김호민, 장영미, 한규수, 문대원, 문연자, 우원홍. 라벤더 에탄올 추출물이 $\alpha-\mathrm{MSH}$ 유도 멜라닌 생성에 미치는 효과. 동의 생리병리학회지, 22: 1444-1448, 2008. 
권승혁, 양희선, 김재용, 박경옥, 손미예, 강갑석, 심기환, 서권일. 산수유 에탄올 추출물의 생리활성. 한국식품영양과학회 지, 38: 287-291, 2009.

모정희, 오수정. 노근 추출물의 항균력 및 세포독성 관한 연구. 아시안뷰티화장품학술지, 9: 167-178, 2011. 모정희, 오수정, 김경란. 노근 에탄올과 열수 추출물의 항산화 활성비교. 한국미용학회지, 19: 809-814, 2013. 민경진, 송진욱, 차춘근. 선학초 추출물의 항산화 및 항암활성. 한국식품위생안전성학회지, 23: 149-156, 2008. 민유홍. 에센셜 오일 배합물의 Propionibacterium acnes에 대한 항균활성. 대한미용학회지, 11: 215-223, 2015. 박상상, 성숙희, 류영배, 조용운, 최영주, 박기훈, 갈상완. 뽕잎 추출물배지를 이용한 눈꽃동충하초(Paecilomyces japonica) 균사체 배양액의 여드름 균(Propionibacterium acnes) 생육억제 효과. 한국버섯학회지, 6: 32-37, 2008a.

박종희, 이종규. 상용약용식물도감. 신일상사, 서울, p559, 2000.

박지영, 박충무, 김진주, 송영선. D-Galactosamine으로 유발된 간손상에 대한 민들레 열수추출물의 예방효과. 한국식품 영양과학회지, $37: 177-183,2008 \mathrm{~b}$.

박초희, 이주연, 이계원, 조영호. 프로폴리스 추출물 함유 하이드로겔 조성물의 성인 여드름 염증 및 홍조완화 효과. 대한 미용학회지, 8: 17-23, 2012 .

서권일, 이상원, 양기호. 산수유 추출물의 항균 및 항산화성. 한국식품저장유통학회지, 6: 99-103, 1999.

서준혁, 현무열, 장성은, 최선영, 김명남, 김범준. 한국인 여드름 환자에서 표피성장인자가 함유된 외용제의 피부 적용에 대한 유효성 및 안전성 평가. 대한화장품학회지, 42: 111-118, 2016.

손호용, 김영숙, 금은주, 권윤숙, 손건호. 피부 여드름 치료제 개발을 위한 천연물의 항균활성 검색. 한국미생물·생명공학 회지, 3: 265-272, 2006.

신경훈, 이혜숙, 김관철. 피지 생성과 여드름. 한국피부장벽학회지, 10: 56-60, 2008.

신유현, 김현정, 이진영, 조영제, 안봉전. 천연 에센셜 오일의 주요 구정물질 분석과 항산화 및 항균 효과에 관한 연구. 생 명과학회지, 22: 1344-1351, 2012a.

안유진, 김선영, 옥주형, 왕현, 박창화, 김성호, 허윤석, 전영희, 박수남. 며느리배꼽 추출물의 항산화 활성. 대한화장품학 회지, 35: 235-241, 2009.

양웅모, 김향미, 장문석, 박완수, 김원남, 김산웅, 최동기, 이학철, 김윤경, 박성규. 연잎 에탄올 추출물이 피부 주름에 미 치는 영향. 대한한의학 방제학회지, $14: 67-75,2006$.

양재찬. 산수유 종자 추출물의 화장품 방부효능에 관한 연구. 오일 및 응용과학 학회지, 33: 333-341, 2016.

양현옥, 최원형, 전병훈, 백승화, 천현자. 산수유 물추추물이 B16/F10 melanoma세포주의 멜라닌 생성에 미치는 영향. 동의생리병리학회지, 16: 818-822, 2002.

양희정, 박수남. 나문재 추출물의 성분 분석. 대한화장품학회지, $34: 157-165,2008$.

오흥근. 오흥근 박사의 향기요법. 양문, 서울, pp82-95, 2000.

유단희, 주다혜, 이수연, 이진영. 연잎 추출물의 항산화 활성 및 멜라노마 세포(B16F10)에서 MITF, TRP-1, TRP-2, tyrosinase의 발현 저해 효과. 생명과학회지, 26: 1115-1123, 2015.

유명심, 나명순. 라벤더 에센셜 오일의 항균력을 이용한 청소년 여드름 억제효과. 아시안뷰티화장품학술지, 8: 1-12, 2010.

이경숙, 최정숙. 여드름병변에서 채취한 Propionibacterium acnes의 분리, 동정 및 생화학적 특성 연구. 한국의류산업학 회지, 8: 571-576, 2006.

이솔지, 이은혜, 신진학, 김선숙, 최은미, 서수련. 유칼립투스 추출물의 Propionibacterium acnes에 의해 유도되는 염증

반응 억제효과. 미생물학회지, 52: 421-427, 2016.

이승헌, 정태석. 피부장벽의 이해. 한국피부장벽학회지, 1: 8-21, 1999.

이선숙, 임지영, 한영숙. 연잎 추출물의 여드름 피부 개선 효과. 아시안뷰티화장품학술지, 10: 405-413, 2012.

이숙영, 황은주, 김지혜, 최영복, 임채영, 김선민. 동백나무 잎과 꽃 추출물의 항미생물 활성 및 항산화 효과. 한국약용작 
물학회지, 13: 93-100, 2005.

이영노. 한국식물도감. 교학사, 서울, p302, 2006.

이은진, 리순화, 임미혜. 에센셜오일의 항균 및 항산화 효과: 팔마로사와 제라늄을 중식으로. 한국미용학회지, 18: 136143, 2012b.

이청무, 박현정, 이신영, 오기숙. 성인여성의 프로폴리스 복용이 고강도 운동에 따른 급성염증반응과 면역기능에 미치는 영향. 한국발육발달학회지, 17: 41-49, 2009.

장문희, 최재송, 배나영, 안택원. 포공영(蒲公英)이 $\mathrm{MC} / 9$ mast cell에서의 Th2 cytokine 발현에 미치는 영향. 사상체질 의학회지, 24: $54-65,2012$.

장소영, 유시용, 김성덕. 식물 추출물의 Pityrosporum ovale 및 Candida albicans에 대한 항진균 활성. 생약학회지, 34 : 303-307, 2003.

정시련, 전경희, 박소영, 장순자. 산수유(山茱英) 종자(種子)의 독성(毒性)과 렉틴 성분(成分). 생약학회지, 24: 177-182, 1993.

조수열, 오연진, 박지윤, 이미경. 고콜레스테롤 흰쥐의 간조직 항산화효소계에 미치는 민들레잎 추출물의 영향. 한국식품 영양과학회지, 32: 458-463, 2003b.

주영승, 김기연, 장성환. 미용 동의보감. 성보사, 서울, $\mathrm{p} 149,2004$.

지중룡, 최영민, 송동용, 최호성, 나종삼, 심관섭. 페퍼민트분말 급여가 비육기 재래흑돼지의 육질 특성 및 지방산 조성에 미치는 영향. 한국축산식품학회지, 31: 224-231, 2011.

최문희, 류은미, 오득실, 신현재. 동백나무 잎 추출물의 여드름 피부 개선 효과. 아시안뷰티화장품학술지, 10: $661-672$, 2012.

최응호. 여드름과 피부장벽. 한국피부장벽학회지, 8: 42-46, 2006.

최지영, 송선영, 이현화. 산수유 에탄올 추출물의 Propionibacterium acnes에 대한 항균 및 항염활성. 아시안뷰티화장품 학술지, 13: 623-630, 2015.

채인경, 유미희, 김혁일, 이인선. 가자, 라벤더, 강향의 항염증 및 항산화 활성 검색. 생명과학회지, 21: 561-567, 2011. 한증호, 우나리야, 이송득, 강명화. 국내 자생 식물 추출물의 항산화 활성 및 항균효과. 한국약용작물학회지, 4: 49-55, 2006.

한정순, 김희정. 민들레(Taraxacum officinale H.) 추출물의 여드름 균에 대한 항균 효과. 국제통합보완대체의학회지, 7 : 3-16, 2011.

허성일, 왕명현. 민들레 추출물의 항산화 활성 및 세포독성 효과. 생약학회지, 39: 255-259, 2008.

황지혜, 남주현, 김우경, 배효상. 선학초(仙鶴草)추출물의 대식세포에서의 LPS-유도 염증반응 대한 효능 연구. 대한본초 학회지, 31: 63-69, 2016. 


\section{中文摘要}

\section{治疗痤疮皮肤有效和安全性成分的研究趋势}

李周妍, 孫效廷

建国大学化妆品工学科, 首尔, 韩国

本研究的目的是探讨治疗痤疮所用成分的安全性和有效性的趋势。“痤疮”是一种慢性炎症性皮肤病。痤疮丙酸 杆菌通过诱导炎症和形成粉刺在痤疮的爆发中起关键作用。目前, 治疗寻常痤疮的主要方法包括口服抗生素, 抗炎药, 类维生素A和局部用药。然而, 长期使用这些药物会引起副作用, 例如: 皮肤刺激、干燥、潮红、瘙 痒和对药物的抵抗。因此, 有效的天然物或替代成分的研究一直在稳步进行。特别是, 已证明抑制细菌活性 的天然提取物对痤疮细菌有效, 同时减少现有痤疮治疗药物的副作用。根据研究, 对痤疮具有抗菌并安全成 分如薰衣草（Lavandula offcinalis），玫瑰草（Cymbopogon martini），桉树（Eucalyptus globulus）， 薄荷（Menthapiperita），茶花（Camellia japonica），莲藕（Nelumbo nucifera G.），山荣英（Corni fructus），空叶苶（Persicaria perfoliate），蒲公英（Taraxacum mongolicum H.），芦根(Phragmitis rhizome), 仙鹤草 (Agrimonia pilosa), 神经酰胺, 蜂胶, 表皮生长因子 (epidermal growth factor, EGF) 等。与现有的痤疮药物相比, 需要进一步测试具有抗菌特性的天然提取物的安全性和功效。

关键词: 痤疮菌, 植物提取物, 抗菌, 表皮生长因子, 皮肤屏障 
